\title{
Effects of sediment disturbance on the structure of benthic fauna in a subtropical tidal creek of southeastern Brazil
}

\author{
Sérgio Antonio Netto, Paulo da Cunha Lana \\ Centro de Estudos do Mar, Universidade Federal do Paraná, Av. Beira-Mar s/n, 83255-000 Pontal do Sul, Paraná, Brazil
}

\begin{abstract}
An experimental analysis of benthic response to sediment disturbance by the blue crab Callinectes danae was carried out in an unvegetated flat adjacent to a salt marsh of the tidal Perequê Creek (Paranaguá Bay, SE Brazil). In order to mimic the natural pits dug by $C$. danae, we made randomly arranged holes, which were subsequently sampled together with undisturbed control sites on 6 different sampling dates, up to $18 \mathrm{~d}$ after disturbance. Analyses of variance were performed to determine if significant differences in macrobenthic population densities and abiotic parameters existed at different sampling times, and between control and disturbed areas. Apart from water content, physical variables did not differ significantly between disturbed and control areas, suggesting that adaptive strategies of the organisms themselves were the main structuring factor of the recolonization process. We provide evidence that active immigration, together with passive deposition, is a major colonization vector for the fauna of local low-energy tidal flats. Recolonization rates of the local fauna paralleled the mobility degrees of individual species or taxa. The numerically dominant surface crawler Heleobia australis and the burrower Lumbrineris tetraura, which are the more mobile species of local macrofauna, also exhibited the more rapid recolonization. There was no evidence that the catchment action of pits actually concentrated food resources, since sediment organic content was essentially similar between disturbed and control sites. Evidence for passive deposition was shown for the sedentariate species Laeonereis acuta, Capitella capitata and an unidentified nematode, whose recolonization rates were moderate and followed the sediment infill of pits. The only species to exhibit evidence of exploiting conditions created by pit simulation was the suspension-feeding bivalve Anomalocardia brasiliana that exhibited fast recolonization rates and higher abundance at disturbed sites. The infaunal predator Sigambra grubii was the only species present at significantly lower densities in pits throughout the experiment, probably due to the removal of its putative food source. Disturbances made by blue crabs, though short-lived, are abundant and frequent enough actually to maintain high densities of species that are otherwise scarce in similar tidal habitats. Such biogenic disturbances can be considered as a mechanism that allows for the persistence and numerical dominance of opportunistic species in tidal flats of local tidal creeks.
\end{abstract}

KEY WORDS: Sediment disturbance $\cdot$ Benthic fauna $\cdot$ Tidal creek $\cdot$ SE Brazil

\section{INTRODUCTION}

Disturbances are environmental fluctuations or destructive events that affect the spatial and temporal patterns of an ecosystem, community, or population and change resources, substrate availability, or the physical environment (Pickett \& White 1985). The role of natural disturbances on marine soft bottoms has been discussed by a number of authors (Thistle 1981, Dayton 1984, Probert 1984, Sousa 1984, Frid 1989,
Barry \& Dayton 1991). Storms, tidally induced sand movements, low temperatures, or salinity fluctuations are natural large-scale disturbances. In contrast, biological disturbances, such as predation or sediment processing by individual animals, are usually smallscale processes, measured in terms of meters or centimeters, though their collective effects can also be a major source of bottom heterogeneity.

Mounds and pits are frequent in intertidal regions and may affect sediment boundary hydrodynamics, 
enhancing erosion or deposition processes. They can be produced by the movements and feeding activities of fish, crabs and birds, by the construction and collapsing of tubes and galleries and also by human activities (McLusky et al. 1983, Kneib 1985, Palmer 1988, Savidge \& Taghon 1988, Warwick et al. 1990, Thrush et al. 1991). Biological disturbance can remove or control prey species, displace epi- or infaunal residents or create new available spaces for colonization.

Considerable research on the recovery potential of brackish and marine fauna after sediment disturbance has long been conducted in temperate areas (Bonsdorff 1985). However, little is known about the succession and dynamics of benthic communities along the tropical and subtropical Atlantic coasts of South America. Tidal creeks, which drain mangroves, salt marshes and 'restingas' (coastal dune vegetation), are very common in estuarine sedimentary plains of the southeastern Brazilian coast. Along those meandering channels, alternating high- and low-energy depositional environments result in benthic associations dominated by suspension- or deposit-feeders respectively (Lana et al. 1989). The blue crab Callinectes danae (Portunidae) is a common predator of benthic organisms in these areas, producing pits when searching for or actually preying upon benthic fauna. Foraging grounds are evidenced by intensely disturbed patches of sediment within smooth undisturbed areas.

This paper reports on benthic response to sediment disturbance in a low-energy flat of a subtropical tidal creek in Paranaguá Bay, SE Brazil. The experiment evaluated the degree of defaunation after artificial disturbances designed to mimic those of Callinectes danae, and the recolonization strategies of individual species or species groups.

\section{MATERIALS AND METHODS}

The study area was an unvegetated flat adjacent to a salt marsh, $800 \mathrm{~m}$ from the mouth of the tidal Perequê Creek, in the high-energy, euhaline sector of Paranaguá Bay (Fig. 1). Perequê Creek drains mangrove areas covered by Laguncularia racemosa, marsh sites colonized by monospecific stands of Spartina alterniflora, and 'restinga' areas. Information on the Perequê

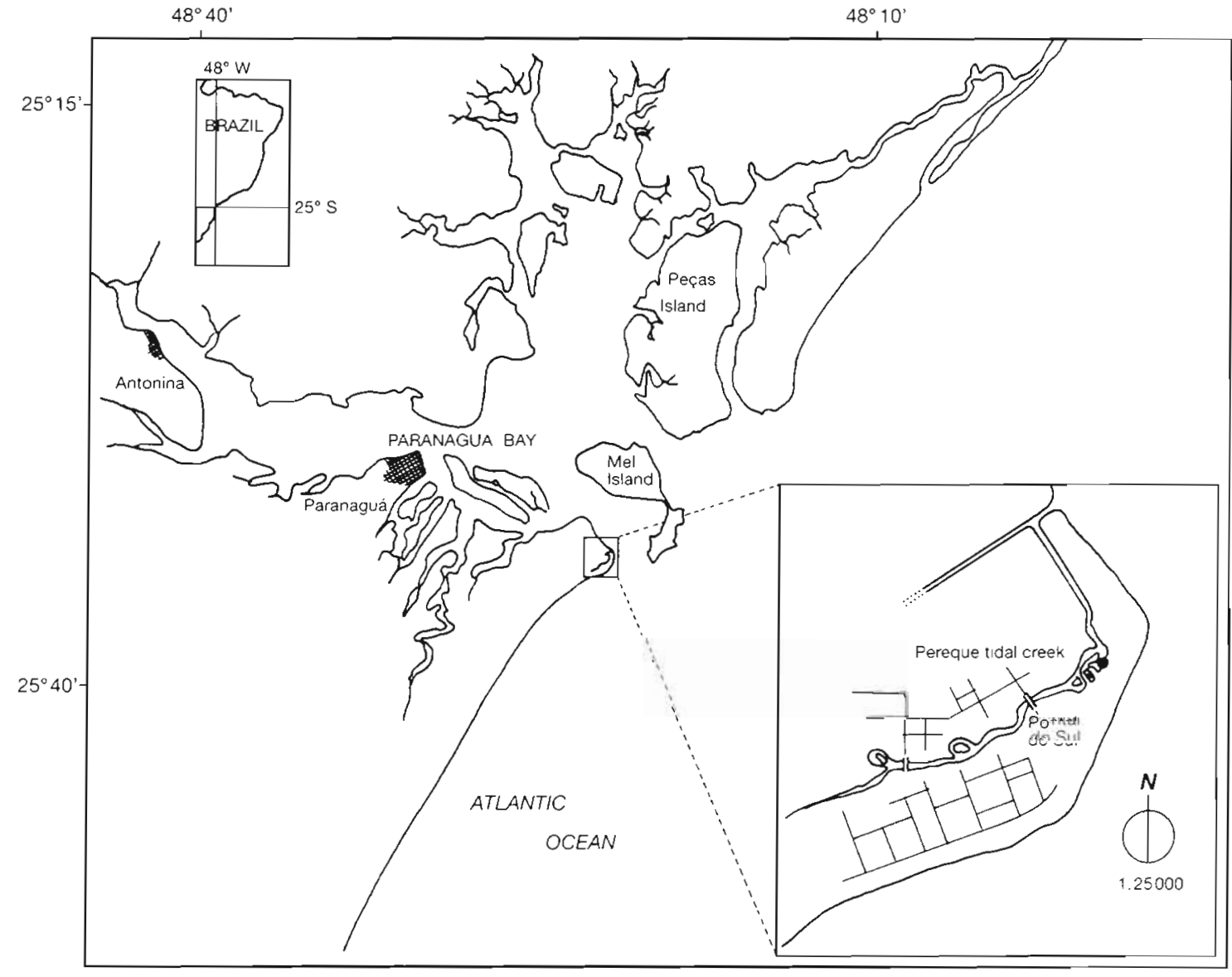

Fig. 1. Location of experiment site in Paranaguá Bay, southeastern Brazil 
tidal creek is provided by Bigarella (1946), Lana et al. (1989), and Marone \& Camargo (1993). Perequê Creek has semidiurnal tides, characterized by diurnal inequalities, with a $0.5 \mathrm{~m}$ neap tide range, a $1.5 \mathrm{~m}$ spring tide range, and a $0.9 \mathrm{~m}$ mean range. At low tide, parts of the creek are completely drained of water; maximum depth reaches $2.8 \mathrm{~m}$ at maximum tidal amplitudes. High-energy sectors, characterized by erosion and sediment transport, are locally represented by fine and well-selected sand in the central canal and concave areas of the creek. Low-energy sectors are represented by extended tidal flats, where the deposition of fine sediment allows for the development of $S$. alterniflora marshes or L. racemosa.

Local crab holes are transient features and do not last longer than 1 to $2 \mathrm{wk}$. Though present in various stages of infill, holes made by the blue crab Callinectes danae in local tidal flats average $10 \mathrm{~cm}$ in diameter with a maximum depth of $10 \mathrm{~cm}$. We did not carry out a systematic estimation of the local rate of disturbance during each tidal cycle; however, up to $50 \%$ of the area of the study site can be disturbed each day by blue crab digging behavior (Fig. 2).

In order to mimic the natural pits made by Callinectes danae, 30 artificial holes, randomly arranged inside an area of $2 \times 10 \mathrm{~m}$, were made with a $10 \mathrm{~cm}$ diameter core tube to a depth of $10 \mathrm{~cm}$, on 7 July 1990 . Thin stakes placed beside holes were used as markers for subsequent sampling. Sets of 5 core-holes, progressively infilling with sediment, were randomly sampled with the same core $2,4,6,8,10$, and $18 \mathrm{~d}$ after disturbance. Five interspersed control samples were taken simultaneously from similar tidal levels on each sampling day.

Benthic samples were sieved through a $0.25 \mathrm{~mm}$ mesh, fixed with $4 \%$ formalin and identified to species under a binocular microscope

Measurements of sediment grain size, organic and water content were made on samples taken with a $2.5 \mathrm{~cm}$ diameter, $5 \mathrm{~cm}$ deep core at 5 control and 5 disturbed sites just after each faunal sampling. Water content was estimated as water loss after sediment drying for $24 \mathrm{~h}$ at $70^{\circ} \mathrm{C}$. Dried subsamples were combusted at $550^{\circ} \mathrm{C}$ for $60 \mathrm{~min}$ in order to determine organic content and then at $1000^{\circ} \mathrm{C}$ for a further 60 min to determine carbonates (Dean 1974). Granulometric data were obtained through the rapid partial sediment analysis proposed by Holme \& McIntyre (1971)

Analyses of variance were performed to determine whether significant differences in macrobenthic population densities and abiotic parameters existed at different sampling times, and between control and disturbed areas. Two-way ANOVAs were used in order to test for differences in sedimentological and faunal parameters between sites (control vs disturbance) and

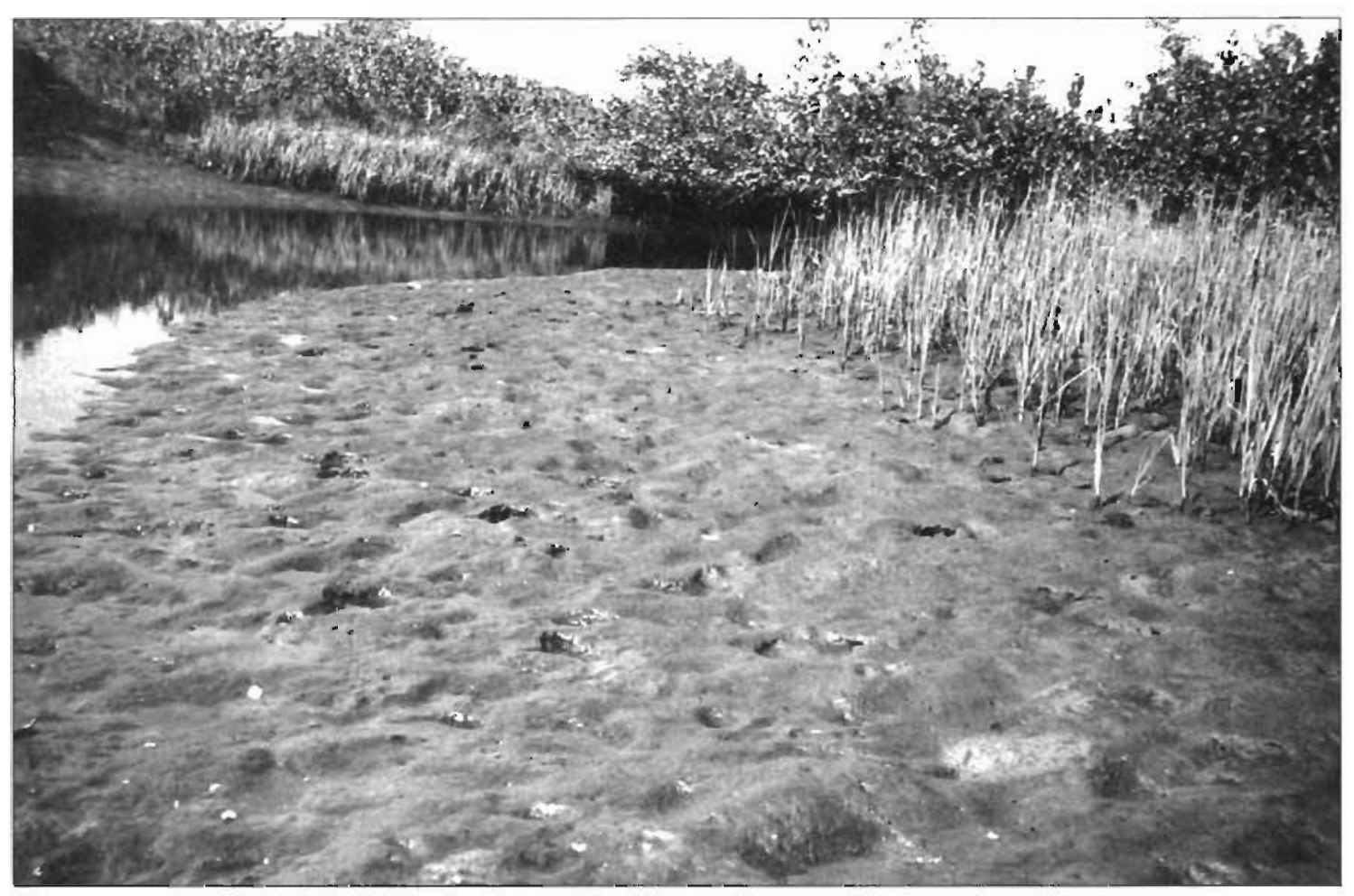

Fig. 2. Tidal flat at Perequê Creek showing patches of sediment disturbed by the blue crab Callinectes danae 
sampling days; 1 -way ANOVAs were carried out to test for differences between control and disturbed sites on each sampling day. Control and disturbed sites (treatments) and sampling days (blocks) were considered as fixed factors. Data were $\log (x+1)$-transformed to increase the normality of the distribution. Bartlett's test was used to check for homogeneity of variances. A multiple comparison Scheffé test $(p<0.05)$ was used whenever significant differences were detected (Hair et al. 1979). Statistical sediment parameters were determined through the GRANULO package, provided by the Sedimentology Lab, Universidade de Rio Claro, São Paulo, Brazil

\section{RESULTS}

Sediment organic content, silt-clay content, carbonate percentage and mean size were found to be indistinguishable at the 0.05 level of significance between disturbed and control sites (Fig. 3, Table 1). Water content was significantly higher at disturbed sites $(p<0.001$; Table 1). Holes displayed a pattern of fast initial infilling between Day 0 (henceforth D0) and Day 2 (henceforth D2), followed by a more gradual accumulation of sediment over the remainder of the experiment. Holes were filled to the level of adjacent sediment within $10 \mathrm{~d}$ and lateral erosion was evidenced by the slumping of pit walls and a progressive increase in hole diameter. Up to D6, water was dammed in pits; water content was significantly higher in disturbed areas than in controls on D2, D4 and D8. After that, no more statistical differences were detected (Fig. 3, Table 2). The results of ANOVAs showed that there were no significant differences at the 0.05 level of significance among sampling days for any of the other physicochemical measures (Table 2).

A total of 24 faunal taxa were identified in the control samples. Average densities ranged between 11 and 1287 ind. $0.008 \mathrm{~m}^{-2}$ (Table 1). The depositfeeding gastropod Heleobia australis, the carnivorous polychaete Lumbrineris tetraura and an unidentified nematode species were numerically dominant and accounted for $85 \%$ of total fauna. Total fauna, species numbers and population densities did not change significantly at control sites over the duration of experiment (Table 2, Fig. 4), with the exception of the polychaetes Laeonereis acuta and Capitella capitata which were present at highest densities on D2 (Table 2).

Total faunal and species numbers did not differ significantly between holes and control sites or among sampling times (Table 1, Fig. 4).

Different distinct recolonization patterns could be discerned after the disturbance (Table 3). Heleobia australis and Lumbrineris tetraura immigrated rapidly into holes, so much so that no significant differences between treatments were detected from D2 on (Table 1, Fig, 4). A similar pattern of rapid recolonization was exhibited by the deposit-feeding polychaete Heteromastus similis, whose densities were at control level at disturbed sites on D2, but were mostly lower than in adjacent sediment on D4, D6, D10 and D18 (Table 2, Fig. 4).

A second pattern was shown by species whose densities returned to control levels between D2 and D4. Densities of the polychaetes Laeonereis acuta,
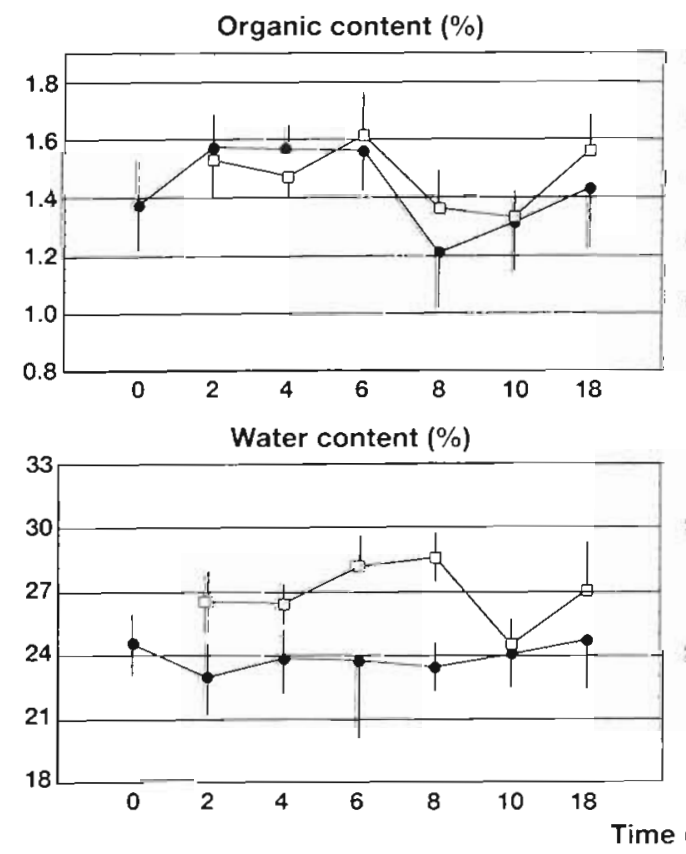

Carbonate content $(\%)$
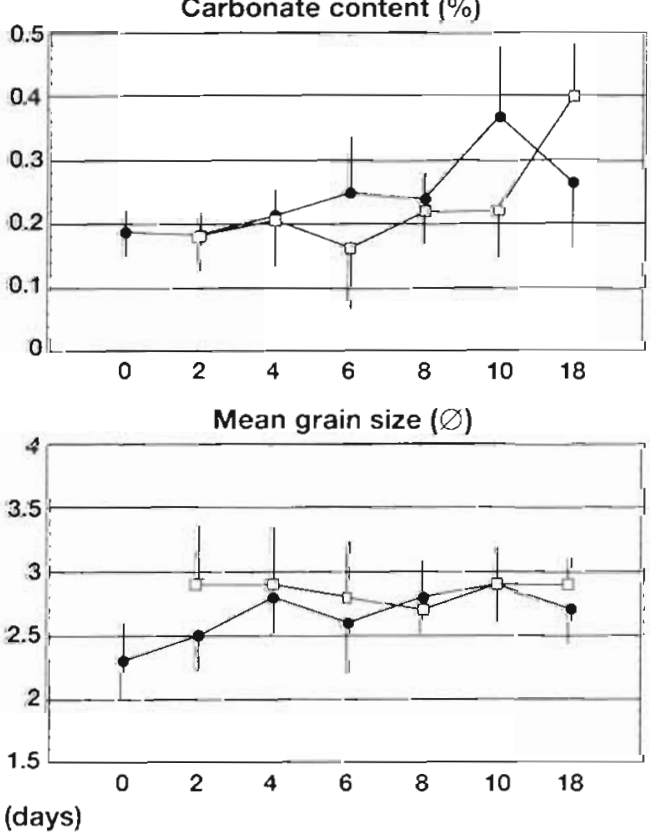

Fig. 3. Variation range in organic, carbonate and water content, and mean grain size of sediment at control ( $\bullet$ ) and disturbed (ㅁ) sites over $18 \mathrm{~d}$ of experiment 
Table 1. Mean and range values of physical and biological variables and results of 2 -way ANOVA evaluating effect of treatments (Control vs Holes) and blocks (sampling days). Analysis performed on $\log (x+1)$-transformed data. Differences between sites determinated by Scheffé post hoc comparisons. NS: no significant differences; ${ }^{\prime} p<0.05 ;{ }^{*} \cdot 0.05<p<0.01$; C: Control; H: Holes

\begin{tabular}{|c|c|c|c|c|c|}
\hline \multirow{2}{*}{ Parameters } & \multicolumn{2}{|c|}{ Mean (range) } & \multirow{2}{*}{$\begin{array}{l}\text { Between sites } \\
\text { (Control vs Hole) }\end{array}$} & \multirow{2}{*}{$\begin{array}{l}\text { Between blocks } \\
\text { (Sampling days) }\end{array}$} & \multirow[t]{2}{*}{ Interaction } \\
\hline & Control & Hole & & & \\
\hline \multicolumn{6}{|l|}{ Sediment } \\
\hline Organic content $(\%)$ & $\begin{array}{c}1.44 \\
(1.33-1.55)\end{array}$ & $\begin{array}{c}1.48 \\
(1.37-1.59)\end{array}$ & NS & NS & NS \\
\hline Carbonate content $(\%)$ & $\begin{array}{c}0.25 \\
(0.20-0.30)\end{array}$ & $\begin{array}{c}0.23 \\
(0.18-0.28)\end{array}$ & NS & NS & NS \\
\hline Water content $(\%)$ & $\begin{array}{c}23.78 \\
(22.87-24.72)\end{array}$ & $\begin{array}{c}26.88 \\
(25.96-27.81)\end{array}$ & $\begin{array}{c}\ddot{*} \\
(\mathrm{C}<\mathrm{H})\end{array}$ & NS & NS \\
\hline Mean grain size $(\varnothing)$ & $\begin{array}{c}3.2 \\
(3.0-3.4)\end{array}$ & $\begin{array}{c}3.2 \\
(3.0-3.2)\end{array}$ & NS & NS & NS \\
\hline Silt-clay content $(\%)$ & $\begin{array}{c}4.57 \\
(4.12-5.01)\end{array}$ & $\begin{array}{c}4.60 \\
(4.16-5.05)\end{array}$ & NS & NS & NS \\
\hline \multicolumn{6}{|l|}{ Macrofauna $\left(0.008 \mathrm{~m}^{-2}\right)$} \\
\hline Heleobia australis & $\begin{array}{c}1287 \\
(1170-1404)\end{array}$ & $\begin{array}{c}1239 \\
(1122-1355)\end{array}$ & NS & NS & NS \\
\hline Anomalocardia brasiliana & $\begin{array}{c}30 \\
(21-39)\end{array}$ & $\begin{array}{c}47 \\
(38-56)\end{array}$ & 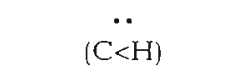 & NS & NS \\
\hline Macoma constricta & $\begin{array}{c}21 \\
(16-25)\end{array}$ & $\begin{array}{c}24 \\
(19-28)\end{array}$ & NS & NS & NS \\
\hline Nematoda spp. & $\begin{array}{c}210 \\
(191-229)\end{array}$ & $\begin{array}{c}174 \\
(155-193)\end{array}$ & $(\ddot{\mathrm{C}}>\mathrm{H})$ & NS & NS \\
\hline Laeonereis acuta & $\begin{array}{c}11 \\
(8-15)\end{array}$ & $\begin{array}{c}6 \\
(2-9)\end{array}$ & $(\dot{\mathrm{C}}>\mathrm{H})$ & NS & • \\
\hline Heteromastus similis & $\begin{array}{c}53 \\
(48-58)\end{array}$ & $\begin{array}{c}34 \\
(30-40)\end{array}$ & $(\ddot{C}>\mathrm{H})$ & NS & $\because$ \\
\hline Capitella capitata & $\begin{array}{c}28 \\
(24-33)\end{array}$ & $\begin{array}{c}19 \\
(14-24)\end{array}$ & $(\ddot{\mathrm{C}}>\mathrm{H})$ & $\cdots$ & NS \\
\hline Sigambra grubii & $\begin{array}{c}17 \\
(16-19)\end{array}$ & $\begin{array}{c}9 \\
(8-11)\end{array}$ & $(\ddot{C}>\mathrm{H})$ & $\because$ & NS \\
\hline Lumbrineris tetraura & $\begin{array}{c}101 \\
(85-117)\end{array}$ & $\begin{array}{c}90 \\
(74-107)\end{array}$ & NS & NS & - \\
\hline Total macrofauna & $\begin{array}{c}1762 \\
(1631-1892)\end{array}$ & $\begin{array}{c}1645 \\
(1515-1776)\end{array}$ & NS & NS & NS \\
\hline No of species & $\begin{array}{c}18 \\
(14-24)\end{array}$ & $\begin{array}{c}17 \\
(14-22)\end{array}$ & NS & NS & NS \\
\hline
\end{tabular}

Capitella capitata and an unidentified nematode species were lower in the holes only on D2; no significant differences in densities were detected after that (Table 2, Fig. 4).

The bivalves Anomalocardia brasiliana and Macoma constricta also presented fast recolonization rates and population densities in pits were already at control levels on D2. A. brasiliana was the only species present at significantly higher densities in holes after disturbance (Table 1). A similar trend was displayed by M. constricta (Fig. 4), though differences in densities between holes and control sites could not be discriminated at the 0.05 significance level (Table 1).

A last pattern was shown by the predator polychaete Sigambra grubii, whose densities were always lower in holes and failed to return to control levels (Table 1).

\section{DISCUSSION}

The distribution and abundance of benthic fauna are frequently correlated with habitat heterogeneity. Changes in spatial heterogeneity may be attributable to changes in the abundance of physical and/or biogenic structures in otherwise homogeneous soft bottom environments (Woodin 1981). Bioturbation by large epifaunal or demersal animals is minor relative to physical processing of the sediment in higher-energy environments (Grant 1983). However, it may be important as a source of habitat heterogeneity at low-energy sites, such as the protected flats of the tidal Perequê Creek.

Small holes created by biological disturbance may first affect benthic species through the alteration of water flow at the water-sediment interface (Jumars \& Nowell 1984). This leads to increased sedimentation 
Table 2. Results of 1-way ANOVA evaluating effect of blocks (sampling days) on sediment and faunal variables. Analysis performed on $\log (x+1)$-transformed data. Differences between sites (Control vs Hole) determinated by Scheffé post hoc comparisons. Densities not significantly different are underlined. NS: no significant differences; ${ }^{\prime} p<0.05 ; \cdot 0.05<p<0.01$; C: Control; $\mathrm{H}$ : Holes

\begin{tabular}{|c|c|c|c|c|c|c|c|c|}
\hline \multirow{2}{*}{ Parameters } & \multirow{2}{*}{ Control } & \multirow{2}{*}{ Hole } & \multicolumn{6}{|c|}{ Days (Control vs Hole) } \\
\hline & & & D2 & D4 & D6 & D8 & D10 & D18 \\
\hline \multicolumn{9}{|l|}{ Sediment } \\
\hline Organic content $(\%)$ & NS & NS & NS & NS & NS & NS & NS & NS \\
\hline Carbonate content (\%) & NS & NS & NS & NS & NS & NS & NS & NS \\
\hline Water content $(\%)$ & NS & NS & $\begin{array}{c}\cdot \\
(\mathrm{C}<\mathrm{H})\end{array}$ & $(\dot{\mathrm{C}}<\mathrm{H})$ & NS & $(\dot{\mathrm{C}<\mathrm{H}})$ & NS & NS \\
\hline Mean grain size $(\varnothing)$ & NS & NS & NS & NS & NS & NS & NS & NS \\
\hline Silt-clay content $(\%)$ & NS & NS & NS & NS & NS & NS & NS & NS \\
\hline \multicolumn{9}{|l|}{ Macrofauna } \\
\hline Heleobia australis & NS & NS & NS & NS & NS & NS & NS & NS \\
\hline Anomalocardia brasiliana & NS & NS & NS & NS & NS & NS & $(\dot{C}<\mathrm{H})$ & NS \\
\hline Macoma constricta & NS & NS & NS & NS & NS & NS & NS & NS \\
\hline Nematoda spp. & NS & NS & $(\ddot{C}>\mathrm{H})$ & NS & NS & NS & NS & NS \\
\hline Laeonereis acuta & 10 D18 D4 D6 D0 D8 D2 & NS & $(\ddot{\mathrm{C}}>\mathrm{H})$ & NS & NS & NS & NS & NS \\
\hline Heteromastus similis & NS & NS & NS & $(\ddot{\mathrm{C}}>\mathrm{H})$ & $(\ddot{C}>\mathrm{H})$ & NS & $(\dot{\mathrm{C}}>\mathrm{H})$ & $(\ddot{C}>\mathrm{H})$ \\
\hline Capitella capitata & 18 D10 D4 D6 D0 D8 D2 & NS & $(\ddot{C}>\mathrm{H})$ & NS & NS & NS & NS & NS \\
\hline Sigambra grubii & NS & NS & $(\ddot{\mathrm{C}}>\mathrm{H})$ & $(\mathrm{C}>\mathrm{H})$ & $\begin{array}{c}\ddot{ } \\
(\mathrm{C}>\mathrm{H})\end{array}$ & NS & $(\ddot{\mathrm{C}}>\mathrm{H})$ & $(\ddot{C}>\mathrm{H})$ \\
\hline Lumbrineris tetraura & NS & NS & NS & NS & NS & NS & NS & NS \\
\hline Total macrofauna & NS & NS & NS & NS & NS & NS & NS & NS \\
\hline No. of species & NS & NS & NS & NS & NS & NS & NS & NS \\
\hline
\end{tabular}

within depressions and to external erosion (Eckman 1983). In our study, however, reduction in pit depth with time was due to slumping of the pit walls, as shown by the progressive increase in pit diameter, rather than to sedimentation or sediment transport across the bed. The only significant difference between pits and the surrounding sediment was the presence of dammed water within depressions during the first days of the experiment. No macroscopic invertebrates were ever noticed swimming in pit water.

Three mechanisms may play a role in the colonization of such small-scale disturbance events: (1) active immigration of adults into pits, through benthic crawling and burrowing, or swimming, (2) passive deposition of animals, by lateral erosion, near-bottom flow or drift in the water column, and (3) benthic or planktonic larval recruitment, by either active or passive dispersal. Although most of the local fauna consisted of juveniles, we were unable to detect any significant benthic recruitment during the experiment, with the exception of Laeonereis acuta and Capitella capitata, which probably recruited between D0 and D2. The relative importance of active or passive dispersal of adults depends upon both the life cycles of the immigrating organisms and the physical and chemical characteristics of the disturbed patches (Savidge \& Taghon 1988). Apart from water content, physicochemical characteristics of holes at the study site did not differ significantly from control areas. This suggests that adaptive strategies of the organisms themselves were the main structuring factor of the recolonization process.

Lateral erosion and sediment slumping within pits could provide an obvious means for the passive recolonization of benthic animals. Savidge \& Taghon (1988) and Thrush et al. (1991) suggested that pit colonization is dominated by passive advection and is proportional to predisturbance densities in the surrounding sediment. We provide evidence that active immigration, together with passive deposition, is a major colonization vector for the fauna of local tidal creeks, at least on the studied spatial scale. Recolonization rates of the local fauna paralleled the mobility degrees of individual species or taxa. The numerically dominant surface crawler Heleobia australis, and the burrower Lumbrineris tetraura, which are the more mobile species of local macrofauna, also exhibited more rapid recolonization. Sediment depressions present a trapping efficiency for particles higher than the surround- 

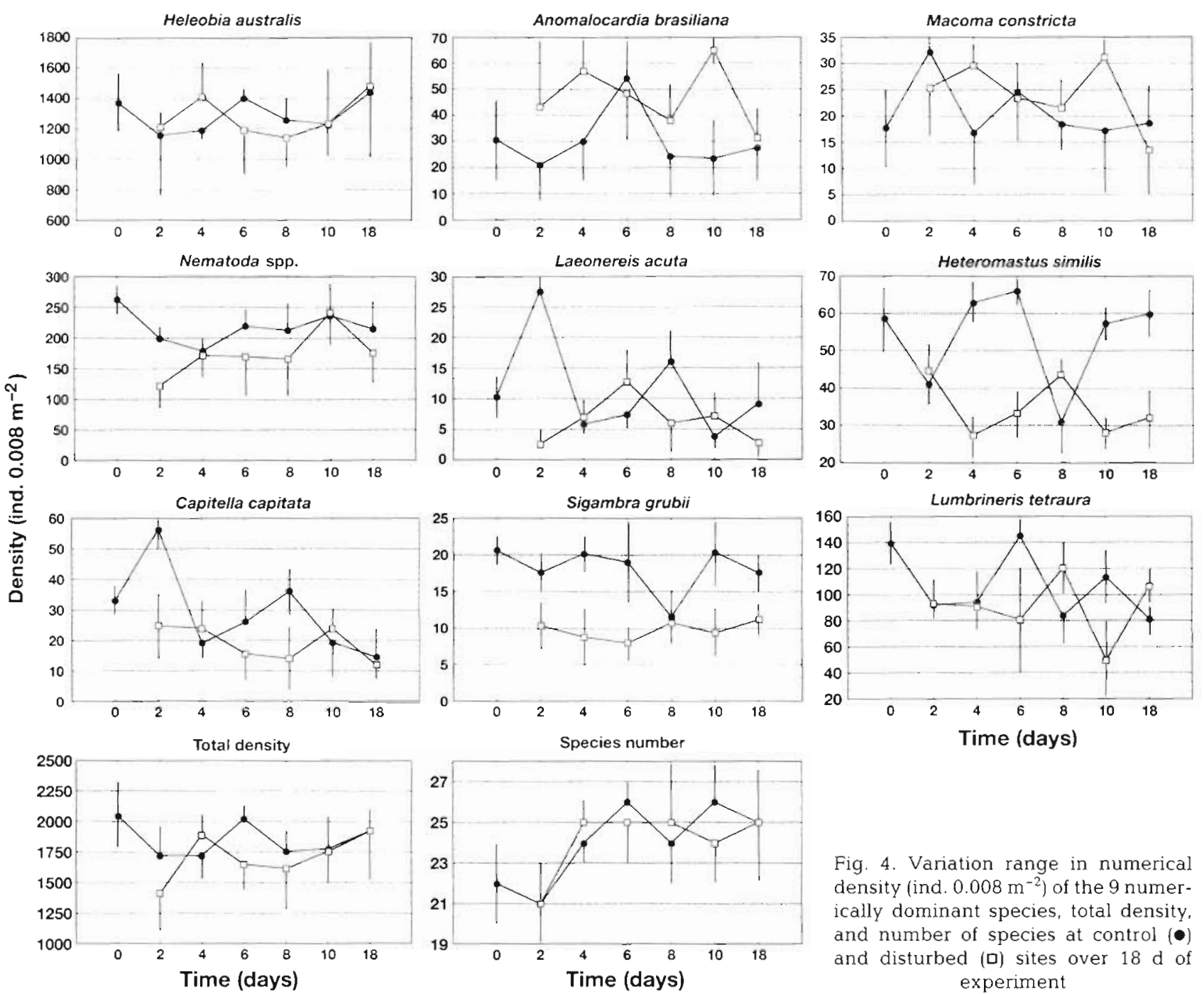

Fig. 4. Variation range in numerical density (ind $0.008 \mathrm{~m}^{-2}$ ) of the 9 numerically dominant species, total density. and number of species at control (ט) and disturbed (a) sites over $18 \mathrm{~d}$ of experiment

Table 3. Recolonization patterns of benthic macrofauna of the tidal Perequê Creek after the simulation of biological disturbance

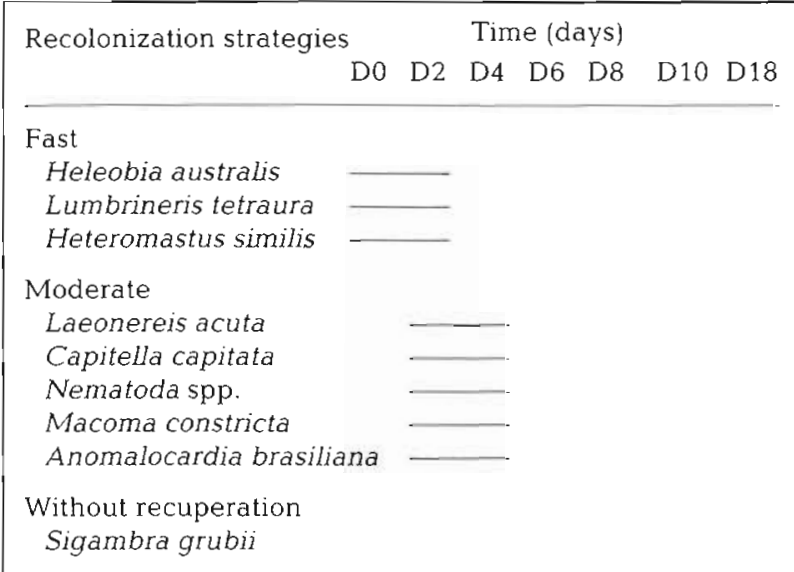

ing sediment surface (Butman et al. 1986). It has been suggested that early colonists in natural disturbances such as biogenic pits actively seek and exploit food resources made available by the disturbance (Thistle 1981, Van Blaricom 1982, Oliver \& Slattery 1985, Oliver et al. 1985, Savidge \& Taghon 1988). However, we were unable to demonstrate that pits concentrated food resources and favored the invasion of scavengers or predators or colonization by pioneer species. There was no evidence that the catchment action of pits actually concentrated food resources, since sediment organic content was essentially similar between disturbed and control sites. In addition, experimental pits were not persistent enough to permit the deposition of higher faunal numbers. Densities of $H$. australis and $L$. tetraura were essentially similar between pits and the surrounding sediment. Therefore, it is likely that their fast recolonization is simply a reflection of high mobil- 
ity coupled with high population densities prior to disturbance. The discretely motile polychaete Heteromas. tus similis, which also exhibited a fast recolonization rate, lives in deeper strata, down to $15 \mathrm{~cm}$ (Bemvenuti 1988). Most individuals were probably not excluded by the simulated disturbance and attained control levels already on D2. It remains unclear why population densities of $H$. similis in pits declined afterwards.

Evidence for passive deposition was shown for the sedentary species Laeonereis acuta, Capitella capitata and an unidentified nematode, as their recolonization rates followed the sediment infilling of pits. These species are subsurface-dwellers, which could protect them from erosion and transport in near-bottom flow but not from being moved with the sediment. Capitellids have been treated as a functional group in similar studies; however, recolonization rates of Heteromastus similis and C. capitata were somewhat different, probably due to their living in different sediment strata. It is likely that an interstitial existence, displayed by most nematodes, reduces their mobility and consequently slows their recolonization rates. Dispersal of nematode adults after sediment scour can be enhanced by fluid flow in turbulent tidal creeks (Palmer \& Gust 1985). However, currents over tidal flats of Perequê Creek do not exceed 30 to $40 \mathrm{~cm} \mathrm{~s}^{-1}$ (E. Marone pers, comm.). This is well below the critical friction velocity required to erode bottom sediment and to suspend nematodes or macrofaunal juveniles within the water column.

The only species to exhibit evidence of exploiting conditions created by pit simulation was the suspension-feeding bivalve Anomalocardia brasiliana which exhibited fast recolonization rates and higher abundance at disturbed sites. McLusky et al. (1983) and Thrush et al. (1991) also detected a rapid recuperation of bivalve densities after biogenic disturbances. This pattern is clearly attributable to water damming inside pits, which affected sediment mass properties such as porosity and compressibility. In such a case, a more continuous supply of suspended material and a facilitation of burrowing in less-compressed sediment would explain higher bivalve densities in disturbed sites.

The infaunal predator Sigambra grubii was the only species present at significantly lower densities in pits throughout the experiment. There is no available evidence on its feeding habits; however, pilargiid polychaetes are usually considered carnivores or omnivores (Fauchald \& Jumars 1979). This unique pattern may be a result of postdisturbance removal of meiofauna, a putative food source for $S$. grubii. Meiofauna are known to be heavily dependent on the flocculent and detrital surficial sediments (Bell et al. 1978) which were removed during the experimental manipulation. We were unable to detect a rapid establishment of this flocculent layer in disturbed sites.
As shown in this study, individual disturbances induced by blue crab feeding activities are short-lived structures, even in comparison with average lifecycles of local benthic taxa. The significance of local biogenic disturbances over small scales could be further reduced due to the capacity for fast recolonization exhibited by highly mobile faunal dominants, as previously proposed by Frid (1989). Low persistence of pits coupled with fast recolonization could support the null hypothesis that blue crab feeding activities do not affect local patterns of faunal distribution. However, disturbances made by blue crabs may cover up to $50 \%$ of the study area, a figure much higher than those previously reported by other authors (Grant 1983, Thrush 1986, Savidge \& Taghon 1988, Thrush et al. 1991). These structures seem to be frequent and abundant enough actually to maintain high densities of species which are otherwise scarce in nearby similar habitats (Lana \& Guiss 1991). Local dominant species, such as Heleobia australis, display opportunistic adaptive strategies (Lana 1986). They are small, short-lived, exhibit high growth and mortality rates and occur in small-scale aggregates within larger homogeneous patches. Frequent biogenic disturbances can be seen as a mechanism that allows for the persistence and numerical dominance of opportunistic species in local benthic associations. As suggested by Thrush et al. (1991), rapid recolonization may be important in maintaining population densities and dominance structure in such small-scale disturbances. However, patchiness in the distribution of benthic organisms exists at different spatial scales (Thrush et al. 1989, Morrisey et al. 1992). The present results cannot be extrapolated to predict the effects of large-scale physical disturbances, such as large sand movements or dredging activities in tidal creek environments.

Acknowledgements. This study was supported by CNPq (Brazilian National Research Council) grants to S.A.N. and P.C.L. We thank Dr Eduardo Jaramillo for the stimulus, Patrícia Sunye for her help in the field, Dr Terezinha Absher for identifying some mollusks, and Jose Claro Neto for the illustrations. Dr Eduardo Marone provided computer facilities and hydrographic data. The manuscript benefited from the comments of 3 anonymous referees

\section{LITERATURE CITED}

Barry, J. P., Dayton, P. K. (1991). Physical heterogeneity and the organization of marine communities. In: Kolasa, J. Pickett, S. T. A. (eds.) Ecological heterogeneity. SpringerVerlag, New York, p. 270-320

Bell, S. S., Watzin, M. C., Coull, B. (1978). Biogenic structure and its effect on the spatial heterogeneity of meiofauna in a salt marsh. J. exp. mar. Biol. Ecol. 35: 99-107

Bemvenuti, C. E. (1988). Impacto da predaçāo sobre Heteromastus similis Southern 1921 e Nephtys fluviatilis Monro 
1937 (Annelida: Polychaeta) em fundos moles estuarinos. Atlântica, Rio Grande 10(1): 85-102

Bigarella, J. J. (1946). Contribuição ao estudo da planície litorânea do Estado do Paraná. Arq. Biol. Tecnol. 1· 75-111

Bonsdorff, E. (1985). Recovery potential of the fauna of brackish-water soft bottoms and marine intertidal rockpools. Ph.D. thesis, A.bo Akademi, Finland

Butman, C. A. (1986). Sediment trap biases in turbulent flows results from a laboratory flume study. J. mar. Res. 44 645-693

Dayton, P. K. (1984). Processes structuring some marine communities: are they general? ln: Strong, D. R. Jr, Simberloff, D., Abele, L. G., Thistle, A. B. (eds.) Ecological communities: conceptual issues and evidence. Princeton University Press, Princeton

Dean, W. E. (1974). Determination of carbonate and organic matter in calcareous sediments and sedimentary rocks by loss on ignition: comparison with other methods. J. sedim. Petrol. 44(1): 242-248

Eckman, J. E. (1983). Hydrodynamic processes affecting benthic recruitment. Limnol. Oceanogr. 28(2): 241-257

Fauchald, K., Jumars, P. A. (1979). The diet of worms: a study of polychaete feeding guilds. Oceanogr. mar. Biol. A. Rev. 17: $193-284$

Frid, C. L. J. (1989). The role of recolonization processes in benthic communities, with special reference to the interpretation of predator-induced effects. J. exp. mar. Biol. Ecol. 126: 163-171

Grant, J. (1983). The relative magnitude of biological and physical sediment reworking in an intertidal community. J. Mar. Res. 41: 673-689

Hair, J. F. Jr, Anderson, R. E., Tatham, R. L., Grablowsky, B. I. (1979). Multivariate data analysis. Petroleum Publishing, Tulsa

Holme, N. A., Mclntyre, A. D. (1971). Methods for the study of marine benthos. IBP, Blackwell Scientific Publications. Oxford

Jumars, P. A., Nowell, A. R. M. (1984). Fluid and sediment dynamic effects on marine benthic community structure. Am. Zool. 24: 45-55

Kneib, R. T. (1985). Predation and disturbance by grass shrimp, Palaemonetes pugio, in soft-substratum benthic invertebrate assemblages. J. exp. mar. Biol. Ecol. 93: 91-102

Lana, P. C. (1986). Macrofauna bêntica de fundos sublitorais näo consolidados da Baía de Paranaguá (PR). Nerítica 1 (3): $79-89$

Lana, P. C., Almeida, M. V. O., Freitas, C. A. F., Couto, E. C. G., Conti, L. M. P., Gonzalez-Peronti, A. L., Giles, A. G., Lopes, M. J. S., Silva, M. H. C., Pedroso, L. A. (1989). Estrutura espacial de associaçóes macrobênticas sublitorais da gamboa Pereque (Pontal do Sul, Paraná). Nerítica 4(1/2): $119-136$

Lana, P. C., Guiss, C. (1991). Influence of Spartina alterniflora on structure and temporal variability of macrobenthic associations in a tidal flat of Paranaguá Bay (southeastern Brazil). Mar. Ecol. Prog. Ser. 73: 231-244
Marone, E., Camargo, R. (1993). A maré do Rio Perequé, PR: caracteristicas e tempo de inundaçào. III. Simpósio de Ecossistemas da Costa Brasileira. Academia Brasileira de Ciências, Sào Paulo, p. 34-36

McLusky, D. S., Anderson, F. E., Wolfe-Murphy, S. (1983) Distribution and population recovery of Arenicola marina and other benthic fauna after bait digging. Mar Ecol. Prog. Ser. 11: 173-179

Morrisey, D. J., Howitt, L., Underwood, A. J., Stark, J. S (1992). Spatial variation in soft-sediment benthos. Mar. Ecol. Prog. Ser. 81: 197-204

Oliver, J. S., Kvitek, R. G., Slattery, P. N. (1985). Walrus feeding disturbance: scavenging habitats and recolonization of the Bering Sea benthos. J. exp. Mar. Biol. Ecol. 91 $233-246$

Oliver, J. S., Slattery, P. N. (1985). Destruction and opportunity on the sea floor: effects of gray whale feeding Ecology 66: 1965-1975

Palmer, M. A. (1988). Epibenthic predators and marine meiofauna: separating predation, disturbance and hydrodynamic effects. Ecology 69: 1251-1259

Palmer, M. A., Gust, G. (1985). Dispersal of meiofaunal in a turbulent tidal creek. J. mar. Res, 43: 179-210

Pickett, S. T A., White, P. S. (1985). The ecology of natural disturbances and patch dynamics. Academic Press, London

Probert, P. K. (1984). Disturbance, sediment stability and trophic structure of soft-bottom communities. J. mar Res 42: 893-921

Savidge, W. B., Taghon, G. L. (1988). Passive and active components of colonization following two types of disturbance on intertidal sandflat. J. exp. mar. Biol. Ecol. 115: 137-155

Sousa, W. P. (1984). The role of disturbance in natural commumities. A. Rev. Ecol. Syst. 15: 353-391

Thistle, D. (1981). Natural physical disturbance in natural communities. Mar. Ecol. Prog. Ser. 16: 223-228

Thrush, S. F. (1986). Spatial heterogeneity in subtidal gravel generated by the pit-digging activities of Cancer pagurus. Mar. Ecol. Prog. Ser. 30. 221-227

Thrush, S. F. Hewitt, J. E., Pridmore, R. D. (1989). Patterns in the spatial arrangements of polychaetes and bivalves in intertidal sandflats. Mar. Biol. 102: 529-535

Thrush, S. F., Pridmore, R. D., Hewitt, J. E., Cummings, V. J. (1991). Impact of ray feeding disturbances on sandflat macrobenthos: do communities dominated by polychaetes or shellfish respond differently? Mar Ecol. Prog. Ser. 69: 245-252

Van Blaricom, G. R. (1982). Experimental analysis of structural regulation in a marine sand community exposed to oceanic swell. Ecol. Monogr. 52: 283-305

Warwick, R. M., Clarke, K. R., Gee, J. M. (1990). The effects of disturbance by soldier crabs Mictyris platycheles on meiobenthic community structure. J. exp. mar. Biol. Ecol. 135: $19-33$

Woodin, S. A. (1981). Disturbance and community structure in a shallow water sand flat. Ecology 64(2): 1052-1066

Manuscript first received: September 3, 1993

Revised version accepted: January 10, 1994 